УДК 378

https://doi.org/10.33296/2707-0255-10(19)-20

ORCID: https://orcid.org/0000-0002-7897-5428*

ORCID: https://orcid.org/0000-0001-8031-4269**

\author{
ПИЛАСВА ТЕТЯНА*, \\ кандидат педагогічних наук, доцент \\ доцент кафедри педагогіки, \\ іноземної філології та перекладу \\ Харківський національний \\ економічний університет імені \\ Семена Кузнеця \\ м. Харків, Україна \\ КОЧИНА ВАЛЕНТИНА** \\ кандидат педагогічних наук, \\ викладач кафедри іноземних мов \\ факультету № 1, Харківського \\ національного університету \\ внутрішніх справ (м.Харків, \\ Україна)
}

\title{
ПРОФЕСІЙНА КУЛЬТУРА МАЙБУТНЬОГО МЕНЕДЖЕРА: ПСИХОЛОГО-ПЕДАГОГІНИЙ АСПЕКТ
}

Анотація. В статті досліджується сутність та взаємозв'язок понять «культура», «професія», «професійна культура». Встановлено, що в структурі професійної культури представлені мотиваційно-ціннісний i операційнодіяльнісний компоненти. Автором представлена низка властивостей професійної культури: інтегративність, соціальність, персоналізація, динамічність і дієвість, безперервність. В статті розглянуто особливості загальних характеристик професійної культури. Встановлено, що сутність професійної культури складають професійна компетентність, моральна культура, професійна майстерність, культура спілкування, особистісні якості, творча реалізація, морально-професійна етика. В роботі зроблено акцент на те, що активне становлення і розвиток інноваційної професійної діяльності вимагає підвищення ефективності формування професійної культури фахівців в різних сферах. Специфічними характеристиками, властивими професійній культурі майбутнього менеджера, є знання основ професійної культури менеджера, усвідомлення себе в якості носія культурних зразків поведінки та професійної діяльності, формування позитивного ставлення до професійної діяльності, до колег, клієнтів. Автором встановлено, що професійна культура, це системне утворення, яке з суспільної точки зору інтегрується за посередництвом конкретних організацій та інститутів, які взаємодіють на основі матеріального 
та інформаційного обміну та виступає елементом взаємозв'язку і взаємодії таких іiі функціональних складових як: традиції, норми, форми виробництва й розподілу ресурсів тощо. В роботі вказано на те, що в структурі професійної культури майбутнього менеджера можна виділити когнітивний, емоційний, комунікативний та рефлексивний компоненти. Автор представляє низку функцій професійної культури: інформаційно-пізнавальну, гуманістичну, комунікативну, нормативну.

Ключові слова: культура, професійна культура, фахівець, менеджер, властивості та характеристики професійної культури.

Постановка проблеми. Насьогодні невід'ємною умовою вдосконалення системи підготовки майбутнього фахівця $є$ формування особистості, яка володіє високою загальною і професійною культурою, здатної до особистісного і професійно-творчого саморозвитку, самореалізації, активного відстоювання своєї позиції в процесі психолого-педагогічного процесу. Серед проблем, пов'язаних 3 професійною культурою випускників, необхідно відзначити: інтеграцію теоретичних знань 3 професійними діями; орієнтацію студентів в професійних цінностях і вміння їх реально оцінити свої можливості; формування готовності до професійної діяльності в умовах багатоаспектного вибору. Компетентні фахівці повинні володіти професійними знаннями та вміннями. Вони зобов'язані вільно володіти інформаційними технологіями, вміти вирішувати нестандартні завдання. Важливим є вміння працювати в команді, чітко виконуючи професійні вимоги, вміти діагностувати ситуацію, прийняти вірне рішення. В значній мірі вирішення цього завдання залежить від принципів організації цілісного педагогічного процесу, які виводять підготовку майбутнього менеджера на особистісний рівень, поєднуючи професійну готовність і суб'єктивну позицію студента, що сприяє усуненню невідповідності між необхідною і реальною підготовкою.

Системі вищої освіти, що займається підготовкою менеджерів, слід приділити значну увагу ефективному цілеспрямованому формуванню професійної культури фахівця. Зараз постає необхідність долучати студентів в процесі навчання у ЗВО до професійної культури на усвідомленому рівні, щоб 
надалі вони могли їі вдосконалювати для досягнення більш високих результатів у професійній діяльності., оскільки ефективність професійної діяльності менеджера після закінчення ЗВО, в кінцевому рахунку, визначається його професійною готовністю і професійною культурою.

Метою статті $€$ розкриття понять та обгрунтування сутності та взаємозв’язку понять «культура», «професія», «професійна культура»; представлення структури та властивостей професійної культури фахівця взагалі i менеджера зокрема, надання специфічних характеристик професійної культури менеджера та узагальнення наукових праць учених щодо цієї проблеми..

Результати останніх досліджень. В результаті аналізу сучасного стану проблеми було встановлено, що психологічні основи професійної культури особистості розглядаються в дослідженнях Є.В. Бондаревской, В.І.Жолдака, I.А. Зимової, В.А.Кальней, Л.С. Колмогорова. В наукових працях досліджується професійна культура педагогів, психологів, військових, інженерів та інших фахівців (А.В. Барабанщиків, О.Н. Береговенко, Н.А. Ісаєва, І.П. Клемантович, А.Л. Короткова, Е.А. Ейхельберг, М.Б. Сидорова, С.І. Уляев,Т.Г. Юсупова і ін.). Однак існує брак досліджень, присвячених формуванню професійної культури майбутніх менеджерів. Це питання має особливе значення, оскільки специфіка їх трудової діяльності вимагає втілення кращих соціально-значущих культурних зразків поведінки.

Виклад основного матеріалу. Поняття «культура» складне i багатогранне, походить від латинського «cultura» - «обробка, виховання, освіта, розвиток, шанування». Американські антропологи А. Кребер і К. Клакхон нарахували понад 150 концепцій і визначень культури. Французький вчений А. Моль - 250, російський вчений А. Е. Кертман - понад 400. Вперше поняття «культура» вжив видатний римський мислитель, оратор i державний діяч Цицерон (106-43pp. до н.е.). Культуру він розглядав, 3 одного боку, як діяльність по перетворенню природи на благо людини, а 3 іншого, як засіб 
удосконалення духовних сил людини, iї розуму. Пізніше поняття «культура» вживалося в якості освіченості, вихованості людини, і в цьому розумінні воно зараз використовується у більшості європейських мов. В епоху середньовіччя поняття "культура" асоціювалось 3 міським укладом життя, а пізніше, в епоху Ренесансу, з досконалістю людини. В кінці XVII ст. поняття «культура» почало набувати самостійного наукового значення.

Зараз поняття «культура» в словниках розглядається як специфічний спосіб організації і розвитку людської життєдіяльності, представлений у продуктах матеріальної і духовної праці, в системі соціальних норм і установ, в духовних цінностях, в сукупності відносин людей до природи , між собою і до самих себе [20, с. 293], іншими словами, це сукупність матеріальних і духовних цінностей, створених i накопичених людством. Сучасний філософський словник під загальною редакцією В.С. Кемерова визначає культуру як форму діяльності людей по відтворенню і оновленню соціального буття, а також пов'язані з цією формою продукти і результати діяльності [16, с. 343]. Крім цього в науковій літературі культура розглядається як: комплекс знань, вірувань, мистецтв, законів, моралі, звичаїв та інших здібностей і звичок, набутих людиною як членом суспільства (Е.Тейлор); соціальні форми і способи облагороджування біологічних можливостей людини (X. Ортега-і-Гассет); система зберігання і передачі соціального досвіду, основу якого становить досягнутий суспільством рівень розвитку сутнісних сил людини (В. Конєв); спосіб життя певного народу, який спільно мешкає на одній території (Т.С. Еліот) тощо.

Другою складовою поняття професійна культура $\epsilon$ професія, що в перекладі з латини означає «заняття, робота». В якості основних елементів професії вчені виділяють спеціалізацію, відділення від інших видів діяльності в рамках поділу праці, досить тривале застосування усталеного способу виконання завдання, а також джерело доходу, яке забезпечує існування людини. Сербського дослідник Д. Маркович до основних характеристик 
професій відносить: тривале виконання певної діяльності; діяльність, яка вимагає спеціальної освіти і набуття навичок; формування особливої професійної поведінки як в рамках професії, так і поза нею; формування професійного інтересу, який часто здійснюється через професійні об'єднання і створення професійних цінностей; прагнення представників деяких професій проявити свій особливий статус по відношенню до інших професій як в сенсі організації, так і в суспільному сенсі, що призводить до ідентифікації людини в професії [13].

Під професією ми розуміємо вид трудової діяльності людини, що володіє комплексом спеціальних знань і практичних навичок, які отримані в результаті цілеспрямованої підготовки. В цьому контексті професія визначає ряд базових елементів культури. Саме культура сприяє підвищенню якісних характеристик професії, надає іiі певну цілісність, стратегічну i тактичну спрямованість, гуманістичну характеристику діяльності члена суспільства. Професія безпосередньо впливає на формування людини, вона робить його відмінним від представників інших професійних груп, породжує різноманітні i несхожі соціальні інтереси. Саме ці соціальні інтереси сприяють об'єднанню людей в професійні спільноти, які прагнуть до відтворення, тобто розвитку себе в професії, розвитку результатів своєї професійної діяльності, передачі накопиченого професійного досвіду іншим особам. На цьому етапі розвитку професії виникає і формується професійна культура.

Феномен професійної культури в науковій літературі традиційно трактується як сукупність теоретичних знань і практичних умінь, пов'язаних 3 конкретним видом праці [2, с.24]. Аналіз літератури дозволяє говорити про те, що одним 3 перших в науковий обіг термін «професійна культура» ввів В. Г. Подмарков, який включав у зміст професійної культури: а) особливі знання даного виду праці, що становлять зміст професії; б) знання даної виробничої ситуації. Під суб'єктом професійної культури В. Г. Подмарков має на увазі конкретний виробничий колектив, цех, бригаду [15, с. 318]. 
В. Г. Ігнатов, В. К. Белолипецкий вважають, що професійна культура - це міра, якість діяльності людини в певній, суворо обмеженою області його професії, в тому виді діяльності, де він відчуває себе цілком комфортно, впевнено, вільно і розкуто [7, с. 63].

За визначенням Н.Б. Крилової професійна культура $є$ системою соціальних якостей, які безпосередньо забезпечують рівень трудової професійної діяльності і визначають ії особистісний зміст, ставлення до праці. Безпосередньо через професійну діяльність кожен фахівець досягає максимальних для себе результатів, прагнучи виявити і реалізувати свій творчий хист. Таким чином він матеріалізує своє ставлення до праці, його особистісна культура повторюється в культурі праці [12, .с. 56]. Ми згодні 3 цим висновком, оскільки в діяльності людини втілюється не тільки досягнутий рівень володіння вміннями і навичками, а ї розкриття здібностей, ступінь розвитку творчих установок, а також готовність реалізувати всю професійну культуру. Саме тому в професійній культура фахівця відображає не тільки зв'язок і взаємодія особистості, професії і суспільства, а й загальну культуру особистості.

Відносно структури професійної культури існує досить велика кількість думок вчених. Однак всі дослідники сходяться на тому, що в структурі професійної культури повинні в тому чи іншому вигляді бути представлені мотиваційно-ціннісний і операційно-діяльнісний компоненти.

Мотивационно-ціннісний компонент передбачає ціннісне ставлення до власної професійної діяльності як до приватної цінності, так і до соціально значимої цінності. Крім того, обов'язковою є наявність позитивного ставлення до обраної професії і подальшого професійного вдосконалення, задоволеність професійфним вибором, володіння етичними нормами професії, наявність професійних здібностей та інших елементів мотиваційної сфери.

Операційно-діяльнісний компонент передбачає наявність професійних знань як основи вдосконалення професійної праці, професійні вміння і навички, 
уявлення i знання про професії, готовності i здатності до здійснення професійної рефлексії, професійної творчості і т.д.

В науковій літературі виділяється низка властивостей професійної культури:

- інтегративність: відображення впливу всіх компонентів професійної культури на особистість в цілому, в сукупності всіх форм, і при досить високому рівні розвитку іï структурних елементів вони впливають на загальний рівень розвитку професійної культури і культуру особистості в цілому;

- соціальність: наявність високого рівня сформованості професійної культури, крім особистого характеру, має і суспільне значення, тобто дозволяє вносити більш істотний внесок в поповнення суспільного багатства;

- персоналізація або особистісний характер професійної культури: привласнення умінь і навичок, що сприяють розвитку професійної культури, i коли ці вміння та навички набувають особистісного сенсу, то відповідні види діяльності здійснюються не тільки з метою уникнення неприємностей, але i 3 усвідомленням значущості даних видів діяльності для задоволення власної особистісної потреби в професійній діяльності і професійному зростанні;

- динамічність і дієвість: відображає спонукальну, мотиваційну силу професійної культури, їі здатність регулювати напрямок розвитку особистісних якостей;

- безперервність: наявність високого рівня професійної культури сприяє безперервному саморозвитку людини в сфері своєї професійної діяльності як для задоволення своїх внутрішніх професійнонаправленних стимулів, так і для підтримки на постійному рівні своєї професійної культури [10, с. 39-40].

Л.Н. Коган зазначає, що професійна культура включає в себе не тільки вимоги, спільні для всіх працівників даної професії, пов'язані з оволодінням відповідною технікою та технологією, а й специфічні вимоги, що залежать від суспільних відносин, від приналежності даної соціально-професійної групи до певного класу [9, с.37]. 
Таким чином, в структурному плані професійна культура особистості соціально-духовно-практичне явище. Вона включає дві групи компонентів, які характеризують їі духовну і діяльнісно-поведінкову сторони. Духовна сторона $\epsilon$ діалектична єдність професійно ідеологічного і психологічного компонентів. Вона включає в себе: систему професійних знань, переконань, культуру професійного мислення, професійні потреби, почуття, волю, професійну мораль, професійну естетику і характеризує духовну готовність людини до здійснення професійної діяльності. Позитивні духовні цінності, що стали надбанням особистості, надають їй вірне орієнтування в житті i цілеспрямованість у роботі, твердість духу, впевненість у вирішенні професійних завдань.

У педагогічних дослідженнях розглядається професійна культура фахівців різних сфер діяльності. Розглянемо особливості загальних характеристик професійної культури. Професійна культура в педагогіці часто трактується як певний ступінь оволодіння членами професійної групи прийомами і способами вирішення спеціальних професійних завдань [14, с. 119]. Це трактування професійної культури може бути віднесене до будь-якого фахівця. Розвиваючи цю думку C.I. Уляев пропонує розглядати професійну культуру як складне системне утворення, що представляє собою упорядковану сукупність загальнолюдських ідей, професійно-ціннісних орієнтацій і якостей особистості, універсальних способів пізнання і гуманістичної технології діяльності. На думку С.І. Уляева в такому визначенні професійна культура постає як вимога суспільства до культурного рівня людей, зайнятих в тієї чи іншій професійній діяльності, і полягає в підвищенні професійної діяльності кожної людини до загальних норм виконання певного виду праці. Крім цього професійна культура $є$ і комплексом якостей, що визначають готовність до реалізації своїх сутнісних сил у конкретній галузі суспільної праці, таких як особистісні знання, умінння, навички, що $\epsilon$ найважливішим показником соціальної зрілості особистості [19, с. 84]. 
Роблячи аналіз сутності професійної культури фахівця, низка вчених (В.К. Белолипецкий, В.Г. Ігнатов) звертають увагу на загальну культуру, професійну майстерність, творчу реалізацію, професійну компетентність, ефективне використання засобів і методів при досягненні мети, раціональність, розважливість, можливість передбачення результатів праці, культуру спілкування, морально-професійну етику. Таким чином, професійна культура $\epsilon$ поєднанням загальної і професійної культури, професійної компетенції та моральної культури [7, с.75]. I.I. Зарецька виділяє компетентність, професійну майстерність, вміння і прагнення проявляти творчу активність в поєднанні 3 технологічною дисципліною та відповідальністю за результати і наслідки своєї праці [6, с.11]. Л.Г. Титаренко, включає до складу професійної культури професійно-технічну підготовку працівника (знання, вміння), його світогляд, ідейно-моральні позиції [18, с.45]. Незважаючи на деякі розбіжності, дослідники сходяться на думці, що сутність професійної культури складають професійна компетентність, моральна культура, професійна майстерність, культура спілкування, особистісні якості.

Таким чином, ми вважаємо, що професійна культура відображає як особистісні характеристики фахівця, так і специфіку самої професії, що дозволяє визначити професійну культуру менеджера як феномен, де відображені загальні характеристики професійної культури, а також особливості професійної діяльності менеджера.

Оскільки сутність професійної культури відображає як загальне, властиве будь-якій професії, так і особливе, в якому проявляється специфіка конкретної діяльності, розглянемо на загальнозначущих характеристиках професійної культури майбутнього менеджера. Загальними характеристиками, властивими фахівцям будь-якого профілю, є працьовитість і працездатність, впевненість в соціальній значущості праці і своєї професії, організаторські здібності, ініціативність, енергійність, знання теорії управління і основ соціальної психології, готовність ефективно і якісно вирішувати виробничі завдання, 
готовність і зацікавленість в оволодінні основами суміжних спеціальностей, в розширенні професійного досвіду; [12, с. 57-58].

Специфічними характеристиками, на наш погляд, властивими тільки професійній культурі майбутнього менеджера, $є$ знання основ професійної культури менеджера, усвідомлення себе в якості носія культурних зразків поведінки та професійної діяльності, формування позитивного ставлення до професійної діяльності, до колег, клієнтів.

Українська дослідниця О. Ельбрехт, ототожнює професійну культуру менеджера з управлінською культурою і характеризує їі як процес і результат соціального середовища, що забезпечує оптимально сприятливі умови праці, індивідуального розвитку і самореалізації всіх членів трудового колективу [5].

Т.Глушман акцентує увагу на дослідженні інформаційно-професійної культури майбутнього менеджера. Вона розглядає їі як складову загальної професійної культури, під якою розуміє особистісні якості, а також знання, вміння та навички здійснювати діяльність по керівництву людьми в найрізноманітніших організаціях, домагатися поставлених цілей, використовуючи працю, професійну освіту, інтелект, мотиви поведінки інших людей $[1 ; 3$, с.11].

Вітчизняні дослідники розглядають професійну культуру, як соціокультурний феномен у двох основних контекстах: 1) як системне утворення, яке 3 суспільної точки зору інтегрується за посередництвом конкретних організацій та інститутів, які взаємодіють на основі матеріального та інформаційного обміну; 2) як професійну культуру, на більш високому рівні

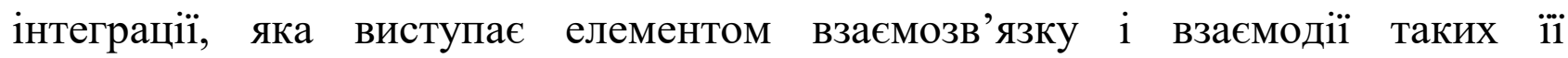
функціональних складових як: традиції, норми, форми виробництва й розподілу ресурсів тощо. Оволодіння загальною i професійною культурою виступає необхідною умовою для переходу людини від репродуктивної діяльності до творчої [4]. 
В структурі професійної культури майбутнього менеджера Войтальянова Я.І. [2, с.28] виділяє наступні компоненти:

1. Когнітивний - включає в себе отримання спеціалізованих знань про цінності професійної культури як основи засобів організації діяльності майбутнього менеджера, усвідомлення їх значущості для професійного становлення, інтелектуальні вміння, пов'язані з переробкою інформації, що засвоюється (високий ступень розвитку мислення, його гнучкість, інноваційний характер, здатність швидкого знаходження варіантів рішень відповідно до нових умов).

2. Емоційний - означає вміння регулювати свій емоційний стан, розпізнавати власні емоції, розуміти емоції інших людей, виявляти емпатію. Високий рівень розвитку емоційного компонента визначає сформованість культури проявів емоцій менеджера.

3. Комунікативний означає вміння встановлення дружньої атмосфери, підтримання взаємодії, розуміння проблем співрозмовника. Цей компонент обумовлений як нормативними вимогами, які передбачають дотримання правил мовного етикету, так і специфікою самої професійної діяльності менеджера, яка характеризується домінуванням мовного (усного) спілкування 3 оточуючими [11 c.71]. Комунікативний компонент характеризує ступень розвиненості культури спілкування менеджера.

4. Рефлексивний - вміння здійснювати рефлексію професійної діяльності, адекватно оцінювати свої професійні можливості і здібності, здатність до самопізнання. Даний компонент є вимогою володіння культурою рефлексії майбутнього менеджера.

Єдність і взаємозв'язок когнітивного, комунікативного, емоційного i рефлексивного компонентів професійної культури майбутнього менеджера характеризують його пізнавальну, мотиваційну i поведінкову сфери $\mathrm{i} \epsilon$ показниками сформованості його уявлень про цінності професійної культури, прийняття системи загальнолюдських і професійних цінностей. 
Всі ці компоненти знаходяться в тісному взаємозв'язку і обумовлюють ефективність формування досліджуваного феномена в сукупності культури мислення, культури спілкування, культури прояви емоцій, культури рефлексії майбутнього менеджера. Вони знаходять відображення в системі ціннісних орієнтацій і проявляються у вигляді спрямованості поведінки і діяльності майбутніх фахівців на цінності професійної діяльності менеджера.

Таким чином, професійна культура майбутнього менеджера $\epsilon$ узагальненим показником його особистісно-професійної компетентності в області менеджменту, визначає найбільш пріоритетні способи здійснення професійної діяльності, відображає його гуманістичну спрямованість і проявляється у внутрішньому (культура мислення, емоційна культура, культура рефлексії) і зовнішньому (культура спілкування, культура проявів емоцій, культура поведінки, культура професійної діяльності, культура зовнішнього вигляду) планах, визначаючи ставлення фахівця до професійної діяльності на основі усвідомлення іiі значущості як державної, громадської, особистісної цінності.

Розглянемо функції культури. М.С. Каган виділяє дві основні функції культури: задоволення потреб людини, суспільства в засобах життєзабезпечення і трансляцію життєвого досвіду [8, с.74]; Е.В. Соколов визначає сім основних функцій культури (освоєння і перетворення світу; накопичення і зберігання інформації; функція психологічної або «проективної» розрядки; комунікативна, сигніфікативна, нормативна, захисно-адаптивна функції). Крім них, автор виділяє чотири функції культури, безпосередньо пов'язані 3 особистістю ( «гомінізаціі», соціалізації, «інкультурації», індивідуалізації) [17, с 45].

В науковій літературі виділяється наступні функції професійної культури майбутнього менеджера. які визначаються виходячи із специфіки професійної діяльності менеджера [2, с.29]: 
- інформаційно-пізнавальна, яка сприяє: формуванню цілісності уявлень про професійну діяльність менеджера, способів іiї освоєння, оволодінню майбутнім менеджером систематизованою інформацією про професійну діяльність менеджера; ініціює розвиток культури мислення майбутнього менеджера;

- гуманістична, яка орієнтує майбутнього менеджера до залучення до загальнолюдських цінностей і цінностей професійної діяльності, формує готовність діяти відповідно до них; створює умови для співпраці, продуктивної спільної діяльності; сприяє розвитку культури прояву емоцій, моральної культури майбутнього менеджера;

- комунікативна, яка задовольняє потребу менедежера у спілкуванні 3 клієнтами, колегами; обумовлює необхідність розвитку культури спілкування майбутнього менеджера;

- нормативна, яка регулює поведінку майбутнього менеджера у відповідності до вимог та норм культури професійної діяльності, прийнятими в даній професійній спільноті; проявляється в культурі поведінки і діяльності майбутнього менеджера.

Висновки. Перспективи подальших досліджень Таким чином, професійна культура менеджера характеризується як узагальнений показник, його особистісно-професійної компетентності в області менеджменту, що визначає найбільш пріоритетні способи здійснення професійної діяльності, яка відображає його гуманістичну спрямованість і виявляється у внутрішньому (культура мислення, емоційна культура, культура рефлексіі) і зовнішньому (культура спілкування , культура прояву емоцій, культура поведінки, культура професійної діяльності, культура зовнішнього вигляду) планах, визначаючи ставлення фахівця до професійної діяльності на основі усвідомлення іiі значущості як державної, громадської, особистісної цінності. Структура професійної культури менеджера включає в себе когнітивний, емоційний, комунікативний i рефлексивний компоненти. Основними функціями 
професійної культури майбутнього менеджера $\epsilon$ інформаційно-пізнавальна, гуманістична, комунікативна, нормативна. В подальших наукових розвідках ми плануємо дослідити проблему формування професійної культури майбутніх менеджерів.

\section{Список використаних джерел:}

1. Беребердин А.В. Формирование информационно-профессиональной культуры будущего менеджера : дис... канд. пед. наук : 13.00.08 /А.В. Беребердин - Челябинск, 2006 - 200 с.

2. Войтальянова Я. И. Формирование профессиональной культуры будущего менеджера в процессе его профессиональной подготовки : дис... канд. пед. наук : 13.00.08 / Я. И. Войтальянова - Красноярск, 2007- 202 с.

3. Глушман Т. М. Компоненти професійної культури майбутнього менеджера організацій / Т. М. Глушман // ScienceRise. Pedagogical Education. 2016. - № 5. - C. 8-13.

4. Дудка Т. Професійна культура менеджера туризму в умовах соціальної модернізації України / Т. Дудка, Л. Бондарина // Вісник Інституту розвитку дитини. Сер. : Філософія, педагогіка, психологія. - 2014. - Вип. 35. C. $75-80$.

5. Ельбрехт О. М. Підготовка менеджерів у вищих навчальних закладах Великої Британії, Канади, США [Текст]: автореф. дис. ... д-ра пед. наук / Є. О. Михайлівна. - Київ, 2010. - 45 с.

6. Зарецкая И. И. Коммуникативная культура педагога и руководителя / И. И. Зарецкая. - М. : Сентябрь, 2002. - 160 с.

7. Игнатов В. Г. Профессиональная культура и профессионализм государственной службы : контекст истории и современность. Учебное пособие / В. Г. Игнатов, В. К. Белолипецкий. -Ростов Н/Д : изд. Центр «МарТ», 2000. $256 \mathrm{c}$.

8. Каган М. С. О субстанции, строении и функциях культуры (к вопросу об основаниях культурологии) / М. С. Каган // Личность. Культура. Общество. - 2004. - Том IV, Вып. 2 (22). - С. 123-134.

9. Коган Л. Н. Профессиональная этика в системе профессиональной культуры / Л. Н. Коган // Методические разработки: профессиональная этика и вуз (Проф.-нравств. культура и учеб.- воспитат. процесс): сб. ст. - Владимир, 1984. - C. 36-39.

10. Короткова А. Л. Формирование профессиональной культуры работника сферы сервиса в условиях профессионального лицея : дис. ... канд. пед. наук / А. Л. Короткова. - Казань, 2000. - 197 с.

11. Кричевский Р. Л. Если Вы - руководитель ... Элементы психологии менеджмента в повседневной работе / Р. Л. Кричевский. - М. : «Дело», 1993. $352 \mathrm{c}$. 
12. Крылова Н. Б. Формирование культуры будущего специалиста : метод, пособие/Н. Б. Крылова. -М. : Высш. шк., 1990. - 142 с. $-632 \mathrm{c}$.

13. Маркович Д. Социология труда Учебник. Москва.: Прогресс, 1988.

14. Педагогика профессионального образования : учеб. пособие для студ. высш. пед. учеб. заведений / Е. П. Белозерцев, А. Д. Гонеев, А. Г. Пашков и др.; Под ред. В. А. Сластенина. - М. : Издательский центр «Академия», 2004. $-368 \mathrm{c}$.

15. Подмарков В. Г. Введение в промышленную социологию / В. Г. Подмарков. - М. : Мысль, 1973. - 412с.

16. Современный философский словарь / под общей ред. д.ф.н. профессора В. Е. Кемерова. - 3-е изд., испр. и доп. - М. : Академический Проект, 2004. - 864c.

17. Соколов Э. В. Понятие, сущность и основные функции культуры : учеб. пособие / Э. В. Соколов. - Л.: ЛГИК, 1989 - 83 с.

18. Титаренко Л. Г. Профессиональная этика и профессиональная культура: опыт социологического исследования / JI. Г. Титаренко // Методические разработки: профессиональная этика и вуз (Проф.-нравств. культура и учеб.-воспитат. процесс) : сб. ст. - Владимир, 1984. - С. 44-47.

19. Уляев С. И. Гуманитаризация образования как фактор формирования профессиональной культуры будущего специалиста : дис. ... канд. пед. наук / С. И. Уляев. - Ставрополь, 2002. - 187с.

20. Философский энциклопедический словарь / Редкол.: С. С. Аверинцев, Э. А. Араб-Оглы, Ј. Ф. Ильичев и др. - 2-е изд. - М. : Сов. энциклопедия, 1989. $-815 \mathrm{c.}$

\section{References}

1. Bereberdin A.V. Formirovanie informatsionno-professionalnoy kultury budushchego menedzhera : dis... kand. ped. nauk : 13.00.08 /A.V. Bereberdin Chelyabinsk, $2006-200$ s.

2. Voytalyanova Ya. I. Formirovanie professionalnoy kultury budushchego menedzhera $\mathrm{v}$ protsesse ego professionalnoy podgotovki : dis... kand. ped. nauk : 13.00.08 / Ya. I. Voytalyanova - Krasnoyarsk, 2007-202 s.

3. Hlushman T. M. Komponenty profesiinoi kultury maibutnoho menedzhera orhanizatsii / T. M. Hlushman // ScienceRise. Pedagogical Education. 2016. - № 5. - S. 8-13.

4. Dudka T. Profesiina kultura menedzhera turyzmu v umovakh sotsialnoi modernizatsii Ukrainy / T. Dudka, L. Bondaryna // Visnyk Instytutu rozvytku dytyny. Ser. : Filosofiia, pedahohika, psykholohiia. - 2014. - Vyp. 35. - S. 75-80.

5. Elbrekht O. M. Pidhotovka menedzheriv u vyshchykh navchalnykh zakladakh Velykoi Brytanii, Kanady, SShA [Tekst]: avtoref. dys. ... d-ra ped. nauk / Ye. O. Mykhailivna. - Kyiv, 2010. - 45 s. 
6. Zaretskaya I. I. Kommunikativnaya kultura pedagoga i rukovoditelya / I. I. Zaretskaya. - M. : Sentyabr, 2002. - 160 s.

7. Ignatov V. G. Professionalnaya kultura i professionalizm gosudarstvennoy sluzhby : kontekst istorii i sovremennost. Uchebnoe posobie / V. G. Ignatov, V. K. Belolipetskiy. -Rostov N/D : izd. Tsentr «MarT», 2000. - $256 \mathrm{~s}$.

8. $\quad$ Kagan M. S. O substantsii, stroenii i funktsiyakh kultury (k voprosu ob osnovaniyakh kulturologii) / M. S. Kagan // Lichnost. Kultura. Obshchestvo. - 2004. - Tom IV, Vyp. 2 (22). - S. 123-134.

9. Kogan L. N. Professionalnaya etika v sisteme professionalnoy kultury / L. N. Kogan // Metodicheskie razrabotki: professionalnaya etika i vuz (Prof.-nravstv. kultura i ucheb.- vospitat. protsess): sb. st. - Vladimir, 1984. - S. 36-39.

10. Korotkova A. L. Formirovanie professionalnoy kultury rabotnika sfery servisa v usloviyakh professionalnogo litseya : dis. ... kand. ped. nauk / A. L. Korotkova. - Kazan, 2000. - 197 s.

11. Krichevskiy R. L. Yesli Vy - rukovoditel ... Elementy psikhologii menedzhmenta v povsednevnoy rabote / R. L. Krichevskiy. - M. : «Delo», 1993. $352 \mathrm{~s}$.

12. Krylova N. B. Formirovanie kultury budushchego spetsialista : metod, posobie/N. B. Krylova. -M. : Vyssh. shk., 1990. - 142 s.

13. Markovich D. Sotsiologiya truda Uchebnik. Moskva.: Progress, 1988. $632 \mathrm{~s}$.

14. Pedagogika professionalnogo obrazovaniya : ucheb. posobie dlya stud. vyssh. ped. ucheb. zavedeniy / Ye. P. Belozertsev, A. D. Goneev, A. G. Pashkov i dr.; Pod red. V. A. Slastenina. - M. : Izdatelskiy tsentr «Akademiya», 2004. - $368 \mathrm{~s}$.

15. Podmarkov V. G. Vvedenie v promyshlennuyu sotsiologiyu / V. G. Podmarkov. - M. : Mysl, 1973. - 412s.

16. Sovremennyy filosofskiy slovar / pod obshchey red. d.f.n. professora V. Ye. Kemerova. - 3-e izd., ispr. i dop. - M. : Akademicheskiy Proekt, 2004. - 864s.

17. Sokolov E. V. Ponyatie, sushchnost i osnovnye funktsii kultury : ucheb. posobie / E. V. Sokolov. - L.: LGIK, 1989 - 83 s.

18. Titarenko L. G. Professionalnaya etika i professionalnaya kultura: opyt sotsiologicheskogo issledovaniya / JI. G. Titarenko // Metodicheskie razrabotki: professionalnaya etika i vuz (Prof.-nravstv. kultura i ucheb.-vospitat. protsess) : sb. st. - Vladimir, 1984. - S. 44-47.

19. Ulyaev S. I. Gumanitarizatsiya obrazovaniya kak faktor formirovaniya professionalnoy kultury budushchego spetsialista : dis. ... kand. ped. nauk / S. I. Ulyaev. - Stavropol, 2002. - 187s.

20. Filosofskiy entsiklopedicheskiy slovar/ Redkol.: S. S. Averintsev, E. A. Arab-Ogly, JI. F. Ilichev i dr. - 2-e izd. - M. : Sov. entsiklopediya, 1989. - 815 s. 


\section{ПЫЛАЕВА ТАТЬЯНА}

кандидат педагогических наук, доцент доцент кафедры педагогики, иностранной филологии и перевода

Харьковский национальный

экономический

университет имени Семена Кузнеца

г. Харьков, Украина

\section{КОЧИНА ВАЛЕНТИНА}

кандидат педагогических наук, преподаватель кафедры иностранных языков факультета № 1, Харьковского национального университета внутренних дел

г.Харьков, Украина

\section{ПРОФЕССИОНАЛЬНАЯ КУЛЬТУРА БУДУЩЕГО МЕНЕДЖЕРА: ПСИХОЛОГО-ПЕДАГОГИЧЕСКИЙ АСПЕКТ}

Аннотация. В статье исследуется сущность и взаимосвязь понятий «культура», «профессия», «профессиональная культура». Установлено, что в структуре профессиональной культуры представлены мотивационноценностный и операционно-деятельностный компоненты. Автором представлен ряд свойств профессиональной культуры: интегративность, социальность, персонализация, динамичность и действенность, непрерывность. В статье рассмотрены особенности общих характеристик профессиональной культуры. Установлено, что сущность профессиональной культуры составляют профессиональная компетентность, нравственная культура, профессиональное мастерство, культура общения, личностные качества, творческая реализация, морально-профессиональная этика. В работе сделан акцент на то, что активное становление и развитие инновационной профессиональной деятельности требует повышения эффективности формирования профессиональной культуры специалистов в различных сферах. Специфическими характеристиками, присущими профессиональной культуре будущего менеджера, являются знание основ профессиональной культуры менеджера, осознание себя в качестве носителя культурных образцов поведения и профессиональной деятельности, формирование положительного отношения к профессиональной деятельности, к коллегам, клиентам. Автором установлено, что профессиональная культура, это системное образование, которое с общественной точки зрения интегрируется посредством конкретных организаций и институтов, взаимодействующих на основе материального и информационного обмена, и выступает элементом взаимосвязи и взаимодействия таких ее функциональных составляющих как: традиции, нормы, формы производства и распределения ресурсов и тому подобное. В работе указано на то, что в структуре профессиональной культуры будущего менеджера можно выделить когнитивный, эмоциональный, коммуникативный и рефлексивный 
компоненты. Автор представляет ряд функций профессиональной культуры: информационно-познавательную, гуманистическую, коммуникативную, нормативную.

Ключевые слова: культура, профессиональная культура, специалист, менеджер, свойства и характеристики профессиональной культуры.

\author{
PYLAIEVA TETIANA, \\ Candidate of Pedagogical Sciences, \\ Associate Professor \\ Associate Professor of the chair of \\ Pedagogy, Foreign philology and translation \\ Simon Kuznets Kharkiv National University \\ of Economics \\ Kharkiv, Ukraine
}

COCHINA VALENTINA

Ph.D., lecturer in foreign languages faculty

№ 1, Kharkov National University of Internal Affairs (Kharkiv, Ukraine)

\title{
FUTURE MANAGERS' PROFESSIONAL CULTURE: PSYCHOLOGICAL AND PEDAGOGICAL ASPECT
}

Abstract. The article examines the essence and relationship between the concepts "culture", "profession", "professional culture". It is determined that the structure of professional culture presents motivational-value and operational-activity components. The author presents a number of properties of professional culture: integrativeness, sociality, personalization, dynamism and effectiveness, continuity. The article considers the features of the general characteristics of professional culture. It is established that the essence of professional culture consists of professional competence, moral culture, professional skills, communication culture, personal qualities, creative realization, moral and professional ethics. The paper emphasizes that the active formation and development of innovative professional activity requires the efficiency increasing of the specialists professional culture formation in various fields. Specific characteristics of the future manager professional culture is the knowledge of $f$ manager professional culture basics, self-awareness as a carrier of cultural patterns of behavior and professional activities, the formation of a positive attitude to professional activities, colleagues, clients. The author points out that professional culture is a systemic structure, that integrates through specific organizations and institutions from a public point of view that interact on the basis of material and information exchange and is an element of interconnection and interaction of such functional components as traditions, norms, forms of production and resource allocation and so on. The paper points out that there exist cognitive, emotional, communicative and reflexive components in the structure of the future manager professional culture. The author presents a number of professional culture functions: information-cognitive, humanistic, communicative, normative.

Keywords: culture, professional culture, specialist, manager, professional culture characteristics. 